\title{
Evidence on the Relationship Between Cash Dividend and Earnings Quality
}

\author{
Herdian Duantoro Putro and Agung Juliarto* \\ Department of Accounting, Diponegoro University, Semarang 50275, Indonesia
}

\begin{abstract}
This study investigated the relationship between the distribution of cash dividends and earnings quality of nonfinancial companies listed in Indonesia Stock Exchange. The quality of earnings was measured by using the absolute value of performance-adjusted discretionary accruals (ADA). With 300 firm-year observations over the period 2011-2013, this study found that companies that pay dividends have better earnings quality than companies that do not pay dividends. Companies that pay dividends in large amounts have better earnings quality than companies that distribute dividend in small amounts. Companies that increase the size of the dividend from the previous period have better earnings quality than the companies that do not raise the size of dividend from the previous period. In addition, this study also showed that companies that have persistent dividends have better earnings quality than the companies that do not have persistent dividend payment during the period of observation.
\end{abstract}

Keywords: Dividend-Paying Status, The Size of the Dividend, Dividend Persistence, Earnings Quality, Absolute Value of Performance-Adjusted Discretionary Accruals (ADA).

\section{INTRODUCTION}

Earnings are important indicator of a company's profitability and can be used to estimate the potential profit in the future. ${ }^{1}$ Bellovary et al. ${ }^{2}$ defines the quality of earnings as earnings ability to reflect actual company's profit and predict future earnings, taking into account the stability and persistence of earnings.

Earnings quality will help decision makers to make the right decision. It will lead to the effective resources allocation that in turn will create productivity, innovation, and the establishment of healthy and liquidity in capital markets. ${ }^{3}$ The quality of earnings in this study is focused on the quality of accrual as proposed by Ref. [4] that uses absolute value of performance-adjusted discretionary accrual (ADA). This measurement can capture the intention of management to manipulate earnings and indicate whether reported earnings reflect the company's actual earnings..$^{5}$

One attraction for investor in the capital market is distribution of dividend offered by issuer. Due to the management freedom to not distribute the entire profit of companies in the form of dividends, the dividend distribution is considered to have information content. ${ }^{6}$

Sirait and Siregar ${ }^{5}$ conducted a study on the relationship between dividend payment and earnings quality in Indonesia Stock Exchange. Their study used similar model with Ref. [7] that conducted in Singapore. The quality of earnings in both studies was focused on the accruals models from Ref. [4]. Both

${ }^{*}$ Author to whom correspondence should be addressed. studies concluded that there is a positive relationship between the distribution of dividends, the increase in dividends from the previous period, the persistence of the distribution of dividends and earnings quality. However, there are still inconsistencies in the results on whether the size of the dividend affects the earnings quality. Meanwhile, Tong and $\mathrm{Miao}^{7}$ found a positive relationship between the size of the dividend and the quality of earnings. Whereas ${ }^{5}$ revealed that the large size of the dividend is not an indicator of earnings quality.

This study tries to analyze the relationship between cash dividends and earnings quality in emerging economy as in Indonesia. There are still inconsistency results between Refs. [5, 7] regarding the relationship between cash dividend and earnings quality. This study extends the research sample of Ref. [5] by using sample of non-financial companies listed on the Indonesian Stock Exchange (IDX) for the period 2011-2013. This study is important given that rapid growth of Indonesian capital market in the last five years 2009-2013. There was an increase of $13.3 \%$ of the companies listed on the IDX during that period.

\section{THEORETICAL FRAMEWORK AND HYPOTHESIS DEVELOPMENT}

\subsection{Dividend Payment and Earnings Quality}

Tong and $\mathrm{Miao}^{7}$ revealed that there are two underlying reasons that the dividend is an indication of good earnings quality. First, it is too difficult for management to distribute cash dividends if 
profits generated by the company do not reflect the actual performance of the company. Second, the distribution of dividend shows the possibility of management to obtain external funding. It will increase the oversight of corporate performance by banks, stock exchanges and fund providers resulting better earnings quality than companies that do not pay dividends.

The dividend has information content about the quality of earnings as proposed by Ref. [8], which become the basic foundation of the creation of the dividend signaling theory, where the research has found empirical evidence that in a state of lack of information owned by the investor, the dividend can be one tool which can be used to reflect the company's performance and the quality of the resulting profits.

The company's ability to pay dividends is strongly influenced by the availability of cash in the company. Breeden ${ }^{9}$ stated that the significant difference between the levels of earnings reported by cash availability indicates problems or fraud that resulted in the company generated earnings quality is questionable. The dividend will encourage companies not to manipulate earnings in the reporting, resulting in actual cash flow. ${ }^{10}$ This is supported by Ref. [11] found that companies conducting financial reporting fraud as indicated by SEC are rarely or not to distribute dividends. Based on these arguments, it leads to the following hypothesis:

H1: Companies that pay dividends have better earnings quality than companies that do not pay dividends.

\subsection{The Size of Dividend and Earnings Quality}

According to Ref. [7] Tong and $\mathrm{Miao}^{7}$ distribution of dividend in large amount indicates higher earnings quality than dividend income in a small amount. Large dividend payment will require the company to have strong cash flow as well. Companies that pay dividends in large amount are supported by large cash flows availability. Large cash flows sourced a small chance of profit is manipulated. In addition, large amounts of dividend will attract more external parties to invest in the company. It results in more parties to oversee the company's performance and monitor managers in reporting profits. Increasing oversight by external parties, in turn will improve quality of reported earnings. Farinha and Moreira $^{12}$ also documented that companies with high earnings quality tend to pay dividends in large amount. Hence:

$\mathrm{H} 2$ : Companies that pay dividends in large amount have better earnings quality than the companies pay small dividend.

\subsection{Increasing Dividend Payment and Earnings Quality}

Caskey and Hanlon ${ }^{11}$ suggested that the company raised its dividend has better earnings quality than earnings quality of company without increasing dividend payment. To be able to increase the dividend takes the trust of management to be able to maintain the dividend level; it is of course supported by a strong cash flow. Lintner ${ }^{13}$ argued that the management will not raise the dividend to a level that cannot be maintained. If the management decided to reduce the size of the dividend it would give a bad signal to the market. Manipulated earnings have not a strong cash base and cast doubt regarding continuity. Based on the arguments above, hence:

H3: Companies that increase the size of the dividends have better earnings quality than companies that do not increase the size of the dividends.

\subsection{Persistency of Dividend and Earnings Quality}

Tong and $\mathrm{Miao}^{5,7}$ found that the company persistently distribute dividend associated with good earnings quality. This is because the company' has a strong cash flow to support persistent dividends distribution. Strong cash flow is not result from manipulated earnings and it reflects earnings quality. ${ }^{5,7}$ Based on those arguments above, it leads to the following hypothesis:

H4: Companies that persistently pay dividends have better earnings quality than companies that do not persistently pay dividends.

\section{METHODOLOGY}

Sample of this study was the non-financial companies listed on the Indonesia Stock Exchange during the period 2011-2013 with certain criteria. The criteria were as follows: company has been listed since 2011, has positive equity, and has financial statement ended on 31 December. Data were obtained from company annual report accessed through IDX website.

The dependent variable in this study was the quality of earnings. Earnings quality is proxied by using Absolute Value of Performance-Adjusted Discretionary Accrual (ADA) as suggested by Ref. [4]. The smaller the value of ADA indicates the lower discretionary accruals. It means less part of earnings that can be manipulated by management. ADA derived from the difference between total accruals (TACC) is fitted value of TACC from the results of the regression equation.

The independent variables in this study were the status of dividend distribution (DIV), the size of the dividend (BIGdiv and SMALLdiv). The increase in the dividend distribution (DIV_CHANGE), and persistence of dividend distribution (PDIV). These variables are proxied by using dummy variables.

Status of dividend distribution is coded 1 if the company distributed dividends in year $t$, and 0 otherwise. ${ }^{7}$ As for the size of the dividend, this study used two variables, namely BIG_DIV and SMALL_DIV. BIG_DIV is coded 1 if the company distributes cash dividends in large amount and 0 otherwise. Dividends were categorized as large if the payout ratio exceeds 0.25 but not more than 2. SMALL_DIV is coded 1 if the payout ratio more than 0 but not more than 0.25 and 0 otherwise. $^{7}$

The increase in the dividend distribution is coded 1 if the company distributes dividend greater than the previous period and 0 otherwise. If company does not distribute dividends in previous period and distribute dividends in the next period is considered as an increase of the dividend distribution. ${ }^{7}$ Persistence of dividend distribution is coded 1 if the company distributed dividends respectively during the observation period of 3 years, and 0 otherwise. ${ }^{7}$ There are six control variables in this study, namely: the size of the firm, external growth prospects, the prospects for internal growth, the performance of the firm, firm age, and leverage.

To test the hypothesis of this study used four different regression models as follows:

Regression models Model 1: to test the Hypothesis 1

$$
\begin{aligned}
\mathrm{ADA}_{i, t}= & \alpha_{0}+\alpha_{1} \mathrm{DIV}_{i, t}+\alpha_{2} \mathrm{SIZE}_{i, t}+\alpha_{3} \mathrm{BTM}_{i, t} \\
& +\alpha_{4} \mathrm{GROWTH}_{i, t}+\alpha_{5} \mathrm{LOSS}_{i, t}+\alpha_{6} \mathrm{AGE}_{i, t} \\
& +\alpha_{7} \mathrm{LEV}_{i, t}+\varepsilon_{i, t}
\end{aligned}
$$


Regression Model Model 2: to test the Hypothesis 2

$$
\begin{aligned}
\text { ADA }_{i, t}= & \alpha_{0}+\alpha_{1} \text { BIG_DIV }_{i, t}+\alpha_{2} \text { SMALL_DIV }_{i} \\
& +\alpha_{3} \text { SIZE }_{i, t}+\alpha_{4} \mathrm{BTM}_{i, t}+\alpha_{5} \mathrm{GROWTH}_{i, t} \\
& +\alpha_{6} \mathrm{LOSS}_{i, t}+\alpha_{7} \mathrm{AGE}_{i, t}+\alpha_{8} \mathrm{LEV}_{i, t}+\varepsilon_{i, t}
\end{aligned}
$$

Regression Model 3: to test the Hypothesis 3

$$
\begin{aligned}
\text { ADA }_{i, t}= & \alpha_{0}+\alpha_{1} \text { DIV_CHANGE }_{i, t}+\alpha_{2} \text { SIZE }_{i, t} \\
& +\alpha_{3} \mathrm{BTM}_{i, t}+\alpha_{4} \mathrm{GROWTH}_{i, t}+\alpha_{5} \mathrm{LOSS}_{i, t} \\
& +\alpha_{6} \mathrm{AGE}_{i, t}+\alpha_{7} \mathrm{LEV}_{i, t}+\varepsilon_{i, t}
\end{aligned}
$$

Regression model 4: to test the Hypothesis 4

$$
\begin{aligned}
\operatorname{ADA}_{i, t}= & \alpha_{0}+\alpha_{1} \mathrm{PDIV}_{i, t}+\alpha_{2} \mathrm{SIZE}_{i, t}+\alpha_{3} \mathrm{BTM}_{i, t} \\
& +\alpha_{4} \mathrm{GROWTH}_{i, t}+\alpha_{5} \mathrm{LOSS}_{i, t}+\alpha_{6} \mathrm{AGE}_{i, t} \\
& +\alpha_{7} \mathrm{LEV}_{i, t}+\varepsilon_{i, t}
\end{aligned}
$$

Where: $\alpha_{0}=$ Constant, $\alpha_{1,2, \ldots, 9}=$ Coefficients, $\varepsilon_{i, t}=$ Residual terms, $\mathrm{ADA}_{i, t}=$ Earnings quality, $\mathrm{DIV}_{i, t}=$ Status of dividend distribution, BIGdiv ${ }_{i, t}=$ Large dividends broad categories, SMALLdiv $_{i, t}=$ Small dividends small category, DIV_CHANGE, $t=$ The increase in the size of the dividend, PDIV $_{i, t}=$ Persistence of dividend payment, SIZE $_{i, t}=$ Size of the company, $\mathrm{BTM}_{i, t}=$ External growth prospects, $\mathrm{GROWTH}_{i, t}=$ Internal growth prospects, $\mathrm{LOSS}_{i, t}=$ Company performance, $\mathrm{AGE}_{i, t}=$ Company age, $\mathrm{LEV}_{i, t}=$ Debt structure.

\section{RESULTS AND DISCUSSION}

This study used non-financial companies listed on the Stock Exchange in 2011-2013. Of the 404 companies listed on the Indonesia Stock Exchange, there were 100 firms per year that met the criteria to be analyzed representing 300 observations over the period 2011-2013. The 100 companies were divided into eight sub-industry classification by IDX consisting: agriculture $5 \%$; mining 10\%; basic industry and chemicals $17 \%$, miscellaneous industry $10 \%$; consumer goods industry $10 \%$; property, real estate and building construction $16 \%$; infrastructure, utilities, and transportation $8 \%$; trade, services and investment $24 \%$. Of 300 data, $69 \%$ observations indicate cash dividend distribution and $63 \%$ observations distribute dividend with large amount. However, only $41 \%$ observations reveal dividend increasing and $46 \%$ indicating persistent dividend distribution.

Table I presents descriptive statistics of 300 firm-year observations for this study. This table shows that earnings quality (ADA) has the lowest 0.000 and the highest value of 1.929. The lower value of ADA indicated the higher quality of earnings. Moreover,

Table I. Descriptive statistics.

\begin{tabular}{lrrrr}
\hline & \multicolumn{1}{c}{ Min } & Max & \multicolumn{1}{c}{ Mean } & Stdev \\
\hline ADA & 0.000 & 1.929 & 0.108 & 0.146 \\
SIZE & 24.499 & 32.997 & 28.606 & 1.779 \\
BTM & 0.000 & 54.194 & 1.203 & 4.086 \\
GROWTH & -8.802 & 8.327 & -0.551 & 1.557 \\
AGE & 25.650 & 6.078 & 4.958 & 0.732 \\
LEV & 0.028 & 26.101 & 1.197 & 2.675 \\
\hline
\end{tabular}

this table also reveals standard deviation of 0.146 and average value of 0.108 .

As for control variables, Table I shows the average value of firm size is 28.606 and average value of external growth is 1.23. Sample of this study also have average of 6.078 year listed on the Indonesia Stock Exchange.

Results of regression analysis of four models are presented in Table II. As can be seen in the table (Model 1), there is a negative coefficient of DIV (-0354) and significant at 0.05 meaning a negative relationship between the status of the dividends distribution (DIV) and ADA. Companies that pay dividends would have little value of ADA. The smaller value of ADA the better the quality of earnings. Thus, the first hypothesis is accepted. Table II also reports that the negative values of BIGdiv $(-0.389)$ and SMALLdiv (-0.262) in Model 2. But the only BIGdiv has statistically significant value. It means that a negative relationship between the size of the dividend and ADA. Since BIGdiv has a significant and higher coefficient than SMALLdiv, it could be concluded that that the company distributed dividends in large amount had better earnings quality than the company making the distribution in small amount. These findings support the second hypothesis.

As can be seen in Table II (Model 3), DIV_CHANGE has a negative coefficient $(-0.247)$ and significant at 0.05 level. Hence, the third hypothesis is accepted. It could be concluded that companies that increase the size of the dividend had better earnings quality than companies that did not increase the size of the dividends. The relationship between dividend persistence and earnings quality is also presented in Table II (Model 4).

This table documents the coefficient of PDIV amounted to -0.850 and significant at 0.01 level. Since the result has a negative direction as predicted, so the fourth hypothesis is accepted. It means that the companies making persistent dividend distribution have better earnings quality than companies that do not persistently distribute dividends. As for control variables, company size consistently has significant influence on ADA in three models. Internal growth only has highly significant influence on ADA in Model 4.

Aforementioned results were consistent with results of previous studies conducted. ${ }^{7}$ Tong and $\mathrm{Miao}^{7}$ argued that the dividend is able to be an indicator to assess the quality of earnings. Companies that pay dividends were required to have a strong cash

Table II. Regression results.

\begin{tabular}{lcccc}
\hline Variable & Model 1 & Model 2 & Model 3 & Model 4 \\
\hline (Constant) & $2.622^{* *}$ & $2.447^{* *}$ & $3.202^{* * *}$ & -0.256 \\
DIV & $-0.354^{* *}$ & & & \\
BIGdiv & & $-0.389^{* *}$ & & \\
SMALLdiv & & -0.262 & & \\
DIV_CHANGE & & & $-0.247^{* *}$ & \\
PDIV & & & & $-0.850^{* * *}$ \\
SIZE & $-0.087^{* *}$ & $-0.082^{* *}$ & $-0.109^{* * *}$ & 0.025 \\
LOSS & 0.417 & $0.434^{*}$ & $0.517^{* *}$ & 0.103 \\
AGE & 0.019 & 0.024 & -0.107 & 0.056 \\
BTM & -0.103 & -0.103 & -0.031 & 0.000 \\
Growth & 0.053 & 0.057 & 0.039 & $0.239^{* *}$ \\
LEV & 0.106 & 0.103 & 0.124 & 0.059 \\
F & $5.187^{* * *}$ & $4.512^{* * *}$ & $5.023^{* * *}$ & $4.832^{* * *}$ \\
Adj. $R^{2}$ & 0.111 & 0.086 & 0.086 & 0.213 \\
\hline
\end{tabular}

Notes: ${ }^{*},{ }^{* *},{ }^{* * *}$ significant at $0.10,0.05$, and 0.01 levels, respectively. Dependent variable ADA 
flow. Strong cash flow was not generated from manipulation of reported earnings. Moreover, the dividend distribution showed management's desire to obtain external funding. This would cause the company's activities to be oversight by external parties. Consequently, it would encourage management to enhance the quality of reported earnings.

Findings of this study also documented that company distributed dividends in large amount have better earnings quality than the company making the dividend distribution in small amount. Tong and $\mathrm{Miao}^{7}$ argues that company making the dividend distribution in large amounts are required to have a very strong cash flow. ${ }^{7,12}$

Increasing the size of the dividend is also a signal of better earnings quality. Results were consistent with results of previous studies conducted. ${ }^{5,7,12}$ To be able to increase the size of dividend, management had to be able to maintain the dividend level. It is, of course, supported by a strong cash flow. Management will not raise the dividend to a level that cannot be maintained. Given that reducing the size of future dividend will give a bad signal to the market.

Based on empirical finding, companies that are able to maintain persistent dividends have better earnings quality. These were consistent with results of previous studies that were conducted by Refs. $[5,7,14]$. Company with persistent dividends certainly has a strong and persistent cash flow to support of dividend distribution. This condition is not resulted from manipulated earnings.

\section{CONCLUSIONS}

This study aims to seek evidence about the relationships between dividend distribution and earnings quality. Quality of earnings is measured by using ADA (Absolute Value of Performance Adjusted Discretionary Accruals) as suggested by Ref. [5]. Sample consists of non-financial companies listed on the Indonesia Stock Exchange during 2011-2013. Results of this study document that dividends paying companies have better earnings quality than companies that do not pay dividends. Large amounts of dividend distribution represent better firm's earnings quality than small amounts of dividend distribution. Companies that increase the amount of the dividend from the previous period have better earnings quality than the company that does not rise the amount of dividend from the previous period. This study also shows that companies that have persistent dividends have better earnings quality than the company that do not have persistent dividend payment during the period of observation. Overall, dividend provides information regarding earnings quality.

Amongst the limitations of this study are short period of study, focusing on non-financial firms, and only using accrual measure of earnings quality. Future study can use other measure of earnings quality and conduct in other emerging economies to obtain broader insights of earnings quality.

\section{References and Notes}

1. K. R. Subramanyam and J. Wild, Analysis of Financial Statements, McGrawHill, USA (2010).

2. L. Bellovary, E. Giacomino, and M. D. Akers, The CPA Journal 75, 32 (2005).

3. Kieso, Weygandt, and Warfield, Intermediate Accounting: IFRS Edition, Second edn., John Wiley \& Sons, USA (2015).

4. S. Kothari, A. Leone, and C. Wasley, Journal of Accounting and Economics 39, 163 (2005).

5. F. Sirait and S. V. Siregar, International Journal of Accounting and Information Management 22, 103 (2013).

6. H. Jogiyanto, Portfolio Theory and Investment Analysis, Gadjah Mada University BPFE, Yogyakarta (2003)

7. Y. H. Tong and B. Miao, Accounting Horizons 25, 183 (2011).

8. S. Bhattacharya, Journal of Economics 10, 259 (1979).

9. R. Breeden, Restoring Trust, Report to the Hon. Jed S. Rakoff, The United States District Court for the Southern District of New York on corporate governance for the future of $\mathrm{MCl}$, Available at: http://law.du.edu/images/uploads/ restoring-trust.pdf (2003).

10. J. Glassman, When numbers do not add up, Kiplinger's Personal Finance (2005), Vol. 59, pp. 32-34

11. J. Caskey and M. Hanlon, Do dividends indicate honesty? The relation between dividends and the quality of earnings, Working paper, University of Michigan (2005)

12. J. Farinha and J. Moreira, Dividend and Earnings Quality: The Missing link? Working paper, ICRA-International Centre for Research in Accounting (2007).

13. J. Lintner, The American Economic Review 46, 97 (1956).

14. D. J. Skinner and E. Soltes, Review of Accounting Studies 16, 1 (2009). 